\title{
Brand Equity of Green Products through Customer Trust and Customer Value
}

\author{
Ivan Diryana $^{\text {a, } 1}$, Gatot Iwan Kurniawan ${ }^{\text {a, } 2}$ \\ ${ }^{a}$ STIE Ekuitas, Jl.P.H.H. Mustofa No. 31 Bandung, 40124, Indonesia \\ 1ivan.diryana@ekuitas.ac.id, ${ }^{2}$ gatot.iwan@ekuitas.ac.id,
}

\begin{abstract}
The increasing demand of enviromentaly friendly products makes a lot of company produce more products with green atribute. Yet not all of those products really have a significant impact on the environment. Greenwashing or an act of misleading the consumer become more common thus affecting customer trust on all green products including those real green company. Trust become more important in green products, this paper is trying to give a glimpse on how to increase trust for green products using customer value. Also how much customer trust give an impact on brand equity of green products.
\end{abstract}

Keyword: Customer Trust, Customer Value, Brand Equity, Green Products.

\section{INTRODUCTION}

According to Joel Makower's (2011) finding, environmentally friendly products less attractive in the market. Environmentally friendly products only able to capture $1 \%$ market share for each product category, because consumers are reluctant to pay more for environmentally friendly products than conventional products (Gan, Wee, Ozanne, Kao, 2008). Environmentally friendly products based on consumer perspective is a product that is not toxic for the environment, good for health, have a responsibility to the social environment, and good for the earth (Durif, Boivin and Julien, 2010).

In Indonesia, according to a survey conducted by $\mathrm{AC}$ Nielsen shows that $66 \%$ of respondents have a high awareness of the environment, $69 \%$ are very concerned about global warming, $72 \%$ are very concerned about the scarcity of water, and $80 \%$ are very concerned about water pollution. (Marketing Magazine, 2011). However, the results of the study by Synovate (2011) showed a low consumption of environmentally friendly products in Indonesia.

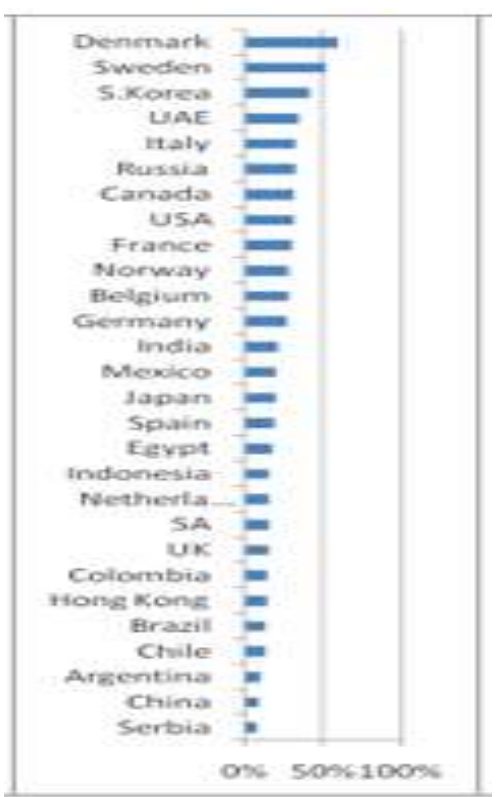

Fig. 1: Consumption Environmental Product Source: Synovate, 2011

According to Laura Reis, president of the company Reis and Reis, who quoted from interviews conducted by Girrbach (2011), environmentally friendly products in fact facing problems which is environmentally friendly products does not have more bargaining power in front of conventional products. Consumer perceptions regarding environmentally friendly product was not better compare to regular products (Girrbach, 2011). Green products are more expensive compare to conventional product thus Veloutsou, Christodoulides and Chernatony (2013), based on their research showed that willingness to pay a premium price can be one measure of brand equity. Brand equity can increase the willingness of consumers to pay more, (Yoo, Donthu, Lee. 2000). Based on what has been disclosed above, eco-friendly products face many obstacles making it difficult to compete, one of the problem is consumers are reluctant to pay more and also the perception of the value of eco-friendly products that are less prominent. Hence the emphasis on brand equity is expected to increase ecofriendly products to reach a larger market. 
According to Chang and Fong (2010) one of the reason companies make their products being environmentally friendly is to increase customer value. So environmentally friendly products have a higher value. Also according to Mahesh (2013), the consumer has the perception that environmentally friendly product has more value than conventional products. While some researchers as Baldauf, Cravens, and Binder (2003) and Netemeyer, Krishnan, Pullig, Wang, Yagci, Deam, Ricks, Wirth, (2004) showed a positive correlation between the value of the brand equity. But in fact environmentally friendly product Brand Equity is not as strong as conventional products. This was revealed by Girrbach (2011) in an article that the problem with today's eco-friendly products has a week brand and they should build strong brands that consumers want to buy green products. If we see the ratings Best Global Brands 2014 conducted by Interbrand, the top 10 are the brands that actually has a lower rank in the World Best Global Green Brands 2014, which was also conducted by Interbrand. Here are the Top 10 Best Global Brands and 10 top ranking Wold Best Global Green Brands 2014.

TABLE 1

Brand Ranking

Source: Brand-Finance dan Interbrand

\begin{tabular}{|l|l|l|}
\hline Rank & Best Global Brands & $\begin{array}{l}\text { Wold Best Global Green } \\
\text { Brands }\end{array}$ \\
\hline 1 & Apple & Ford \\
\hline 2 & Google & Toyota \\
\hline 3 & Coca Cola & Honda \\
\hline 4 & IBM & Nissan \\
\hline 5 & Microsoft & Panasonic \\
\hline 6 & GE & Nokia \\
\hline 7 & Samsung & Sony \\
\hline 8 & Toyota & Adidas \\
\hline 9 & Mc. Donalds & Danon \\
\hline 10 & Mercedes Benz & Dell \\
\hline
\end{tabular}

Increasing customer value on environmentally friendly products do not in fact increase the brand equity of environmentally friendly products. Ford was ranked first in the World Best Global Green Brands, the Best Global Brands ranking only be in a position to 39 .

Environmentally friendly products are also experiencing other problems, namely the emergence of greenwashing. Greenwashing is the practice of disinformation on the accuracy of environmental conservation (Laufer, 2003). The increasing of Eco-friendly movement lately making companies launched a range of environmentally friendly products. But the actual effect of the product on the preservation of the environment is not significant, greenwashing. As a result of greenwashing, lower consumer confidence in the environmental friendly products (trust) and increase the perception of risk of product failure is associated with preservation of the environment (perceived risk).

Delmas and Cuerel (2011) says greenwashing is an act which mislead consumers about environmentally friendly activities of a company's reliability or usefulness of a product / service to the environment . The increasing of greenwashing phenomenon can cause consumer confidence in the green products who is truly environmentally friendly decreasing. The increasing of eco-friendly movement lately, making companies are tempted to participate in the movement even though green attributes on the product is only a little and actually do not have a significant impact on the environment (Farnsworth, 2000). Greenwashing occurs as a result of the company is not required to publish environmental conservation policies that they claim or are not required to verify the statement of claim to be friendly to the environment using a third party (Montiel and Ramus 2005). Often, in fact, consumers become doubtful whether the companies who claim to be environmentally friendly truly environmentally friendly (Montiel \& Ramus, 2005).

Greenwashing has led to doubts on the part of stakeholders to create a company that is truly environmentally friendly, thus making it more difficulties in implementing environmentally friendly marketing strategy (Crassous and Gassmann, 2011). Greenwashing affect the image, satisfaction and confidence that is driving brand equity (Chen, 2010). Naturalnews.com (2010) reported that often the products are labeled environmentally friendly does not really environmentally friendly, these products can be only little effect on environmental sustainability or misleading.

Objective of study

Brand equity could be the answer to increase green product sales, thus it is important to know the relationship from customer trust and customer value on brand equity in green product due to the problem from those variables on brand equity. Therefore the objective of this study is to investigate a relationship brand equity dimension with green purchase intention.

\section{LITERATURE REVIEW}

\section{A. Brand Equity}

According to Farquhar (1989) brand equity is the added value provided by the brand of the product. Farquhar said that the brand equity has added value and it is depend on the existing perspective. Brand equity can be seen from company point of view. Farquhar stated that there are three important elements in building a strong brand. Those elements are positive evaluation of the brand, accessing attitude toward the brand and consistent brand image. 
David A. Aaker (1991) defined brand equity as the set of brand assets and liabilities linked to the brand, its name and symbols, that add value to, or subtract value from, a product or service. These assets include brand loyalty, brand awareness, perceived quality and brand associations. It is the consumers' perception of the overall superiority of a product carrying that brand name when Compared to other brands.

In the service sector Berry (2000) revealed that brand equity can be positive and also can be negative. Positive brand equity is the degree of marketing advantages possessed by a brand compared to competitors that are not recognized or only partially recognized. Negative brand equity is the degree of marketing disadvantages associated with a specific brand. According to Berry, there are two dimensions of brand equity is brand awareness and brand meaning.

Consumer based brand equity is the result of the distinguishing effects of brand knowledge on consumer response to the marketing brand (Keller, 2013), or it can be said that the brand equity is a different response from the consumer to a product due to the knowledge of the brand where knowledge is influenced by the marketing efforts of the product.

According to Yu-Shan Chen (2010) green brand equity, is a set of assets and liabilities of the commitment of the environment and environmental concerns associated with the brand, brand names and symbols that can increase or decrease the value in a product or service. Green brand equity is as good as what an eco-friendly brand is perceived by consumers and how much the value of green principles can be added as value for the brand, depending on the product image as a brand that cares for the environment.

Although it looks definition from Yu-Shan Chen (2010) is more suited to the object of this study in green products, but the definition of Yu-Shan Chen (2010) which is an extension of the previous research, when viewed from the operationalization of variables actually what $\mathrm{Yu}$ Shan Chen (2010) did is comparing the green products with another green products, thus it is not in accordance with the phenomenon observed in this study. Therefore in this study brand equity defines according to Aaker (1991) which is used as a reference because it felt more appropriate and also the definition from Aaker (1991) is commonly used by many brand equity research.

\section{B. Customer Trust}

Definitions that commonly used about consumer trust is from Moorman, C., Zaltman, G. and Deshpande, R. (1992) which states that trust is a willingness to rely on partners who have believed. According Moorman et, al. (1992) trust can be viewed in two perspectives. The first, trust is seen the confidence on a feature or aspect of the quality of a relationship, while another view trust as a determinant of the quality of the relationship. Moorman et, al also view trust as determinants and conducted a series of studies. They investigated the relationship of trust with the use of marketing research among researchers.

Ganesan (1994) examined trust on the relation between vendors and retailers. According Ganesan (1994) trust is a belief, establishment or an expectation of peer exchange as the result of expertise, reliability and intentions of the partners. Definition of trust expressed by Ganesan reflect two different kompenen: credibility and benevolence. Credibility is based on the extent to which retailers believe the vendor has the appropriate expertise to get the job done effectively and reliably. Virtue is based on the extent to which retailers believe that the vendor has the mutual intention and motive when a new conditions arise, the conditions in which the agreement was not made.

According Sidersmukh, Singh, and Sabol (2002) consumer trust is owned by the expectation that a service provider can be expected to provide services as promised and reliable. Sidersmukh, et al., (2002) conceptualized the customer confidence in the services sector as a multifaceted construct that includes the behavior of frontline employees and managerial policies.

In general, the definition of the customer's trust is not much different from each other, which is the willingness of the parties to rely on the other party. However, the definition of green trusts proposed by Chen and Chang (2013), is the willingness to rely on products, services or brand that are the result of credibility, virtue and ability of the products relating to its performance on the environment, Chen and Chang definition is looks suitable for this research. The definition emphasizes environmentally friendly feature that differentiates between green products and conventional products. Greenwashing phenomenon will harm customer trust on green products, as described in the introduction chapter.

\section{Customer Value}

Customer value associated with the use of a product or service, and the perception built by a consumer and not formed by the seller or other stokeholder (Wang and Lo., 2003). Zeithaml (1988) define the customer's perceived value as a comprehensive assessment of the consumer to use the product based on the perceived of received and given. Consumers expense of both money and a variety of other resources such as time, energy, effort and others to obtain a product or service. For some consumers that the form of money is very important so they will look for products with the most convenient price. Consumers who feel money is important can reduce the sacrifice in monetary form will 
increase the perceived value of the product (Zeithaml, 1988).

According to Slater and Naver (2000) value is created when the consumer benefits associated with products or services exceeds the life cycle cost offered to consumers. Benefit is developed in the form of tangible benefits for commercial customers through increasing unit sales or margin improvement. Life cycle costs include the cost of search, the operational costs and disposal costs, and the cost of the purchase. Ulaga and Chacour (2001) says that the concept of value is a fundamental constituent of relationship marketing. Even he said that delivering superior value to customers is a key factor in creating and maintaining longterm bound in the industry. According Ulaga and Chacour (2001) consumer value perception is the perception of the worth in monetary units from a series of economic, technical and social benefits received by consumers in exchange for a fee and taking into account other alternative offers.

\section{CONCEPTUAL FRAMEWORK}

Ambler (1997) states that trust greatly affect brand equity. Kumar and Purwar (2013) showed a significant correlation between trust with the overall brand equity. Chen (2010) proved the influence of environmental trust to brand equity environment. Kilmpasani (2012) study confirmed Chen's (2010) finding that the trust has a significant relationship with the green brand equity in consumer products environmentally friendly in Greece.

Perceived value relationship with the brand equity can be seen from the relationships studied by Baldauf, Cravens, and Binder (2003). Baldauf et., Al (2003) stated that the Perceived value and brand equity has a positive relationship. Netemeyer, Krishnan, Pullig, Wang, Yagci, Deam, Ricks, Wirth, (2004) says that the product quality, perceived value, and uniqueness as well as the desire to pay a premium price is the essence of brand equity based on consumer perceptions. Kamakura and Russell (1993) say that the perceived value of the components of brand equity. Thus based on above previous research we propose our research framework.

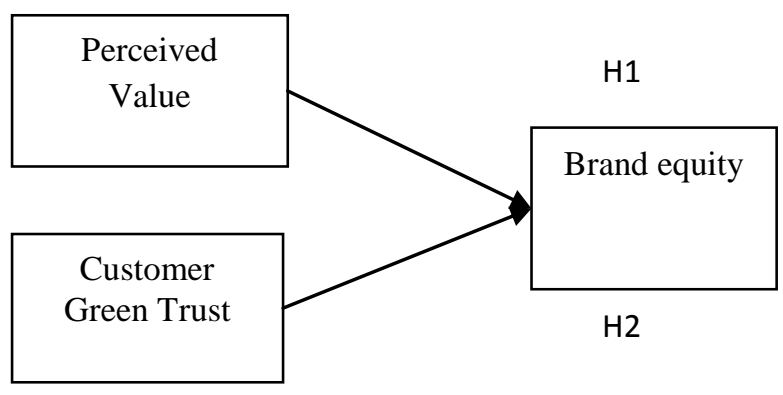

Fig. 2: Research Framework
H1. Perceived Value has a significant direct effect on Brand Equity.

H2. Customer Green Trust has a significant direct effect on Brand Equity.

Below are the items use to measure customer value

- The product give more benefit for me

- This product have more value compare to others

- I don't mind giving more effort in order to acquire this product

Green Trust is measured using Chen (2010) measurement

- Believe that products feature of the environmental friendly in general is reliable

- Believes that the environmental friendly function of the product is reliable

- In general customer believe that environmentally friendly claims on product is trustworthy

- The Performance of environmentally friendly products are match with the expectations

- Products fulfill its promise to improve the environment .

For brand equity we use Aaker (1991) brand equity dimensions: brand loyalty, brand awareness, brand association, perceived quality.

- I will purchase products with the same brand again

- I will recommend the products with the brand to other people

- I have ever heard about brand

- I know how product look like

- The products features fulfill my needs

- The products fits with my lifestyle

- Product have excellent performances

- The product features match with the promised ones

- I will consider to purchase green product

- I would buy green products in order to save the environment

The research was conducted in Bandung using consumers who have already used the product from The Body Shop, since it is well known brand for producing environmental safety cosmetics. Purposive sampling method is used since there is no information about the green product population in Bandung. We are able to collected 82 respondents who are match with the research requirement. Data was collected on a Likert type scale, where 1 indicated minimum agreement and 5 indicated maximum agreement. Then we processed the data using partial least square method considering the flexibility given by the PLS method and the total respondent that we can collect during this research, SmartPLS version 2 is used. PLS is a soft 
modeling approach to SEM with no assumptions about data distribution (Vinzi et al., 2010). Thus, PLS-SEM becomes a good alternative to CB-SEM when the following situations are encountered (Bacon, 1999; Hwang et al., 2010; Wong, 2010): 1. Sample size is small. 2. Applications have little available theory. 3. Predictive accuracy is paramount. 4. Correct model specification cannot be ensured.

\section{RESULT}

Reliability Test: We applied Cronbach's Alpha reliability method to check the reliability of all items in the questionnaire using SmartPLS. The reliability coefficient value was highly significant and depict high reliability of the questionnaire:

TABLE II

Cronbach's Alpha Reliability of the Measure

\begin{tabular}{|l|r|} 
& Cronbachs Alpha \\
\hline Brand Equity & 0.920 \\
\hline Customer Value & 0.726 \\
\hline Green Trust & 0.826
\end{tabular}

Now let us take a look at the loading factor for dependent and independent variables that we observe.

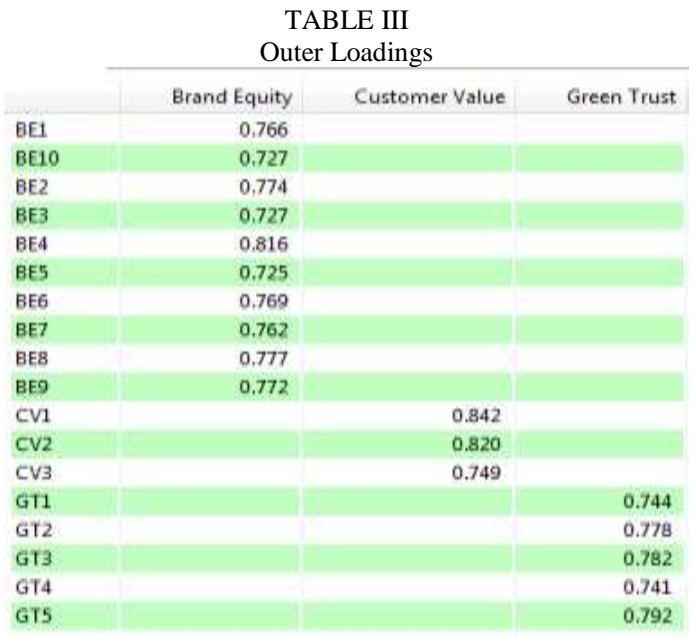

From the result in figure 3 , we can conclude that all the indicator are pass the minimum requirement, according to Hulland (1999), 0.70 or higher is preferred. If it is an exploratory research, 0.4 or higher is acceptable.

Composite reliability should be 0.7 or higher. If it is an exploratory research, 0.6 or higher is acceptable. (Bagozzi and $\mathrm{Yi}, 1988$ ), as we can see from the table 4 the composite reliability are higher than 0.7 .
TABLE IV

Composite Reliability

\begin{tabular}{|l|r|}
\hline & Composite Reliability \\
\hline Brand Equity & 0.933 \\
\hline Customer Value & 0.846 \\
\hline Green Trust & 0.878 \\
\hline
\end{tabular}

High levels of internal consistency reliability have been demonstrated among all variables. Traditionally, Cronbach's alpha is used to measure internal consistency reliability in social science research but it tends to provide a conservative measurement in PLS-SEM. According to Bagozzi and Yi, (1988) also Hair et al. (2012) suggested the use of Composite Reliability as a replacement. From Table 5 , such values are shown to be larger than 0.6 , so high levels of internal consistency reliability have been demonstrated among all three reflective latent variables.

TABLE V

Average Variants Extracted

\begin{tabular}{l|r}
\hline & AVE \\
\hline Brand Equity & 0.581 \\
\hline Customer Value & 0.647 \\
\hline Green Trust & 0.589 \\
\hline
\end{tabular}

To check convergent validity, each latent variable's Average Variance Extracted (AVE) is evaluated. For Average Variants Extracted (AVE), It should be 0.5 or higher (Bagozzi and Yi, 1988) and from table 6 we got all the variable are higher than 0.5 .

Structural Model Analysis

A bootstrapping procedure using 500 sub samples was performed to evaluate the statistical significance of each path coefficient

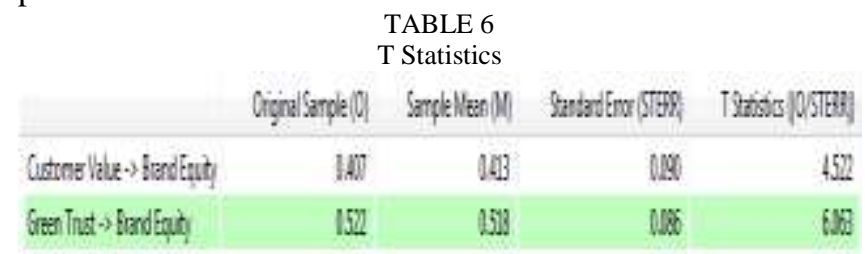

The relationship between Customer Value and Brand Equity was insignificant with $\beta=0.407$ and $t=4.522$ (table value is 1.96 at 0.05 degree of freedom > 120) indicating that the Customer Value has direct positive insignificant influence on the Brand Equity. The relationship between Green Trust and Brand Equity was insignificant with $B=$ 0.522 and $t=6.063$.

The result for path coefficient can be examine from the path diagram below. 


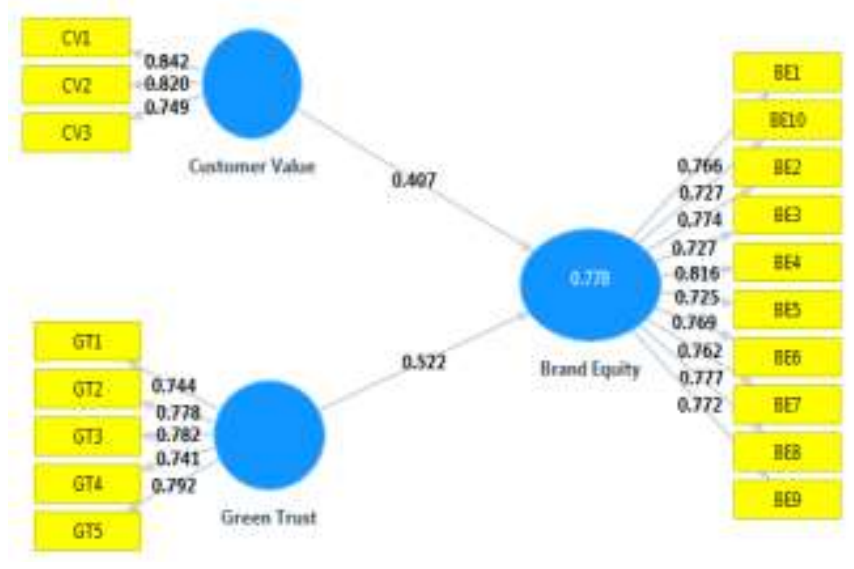

Fig.3 : Result from PLS Algorithm

As we can see from the above diagram, Customer Value coefficient is 0.407 and Green Trust coefficient is 0.522 . $\mathrm{R}$ square is 0.778 for this model, only $77,8 \%$ variants can be explained in this model.

\section{CONCLUSION}

Our research is trying to give a glimpse on how customer value and green trust have an impact on brand equity, using customers with experience on the products we can have understanding on how both independent variables affect brand equity. From this study we know that green trust have bigger impact on brand equity thus green products must able to build trust in the customers mind through many way, especially about its functionality related to environmental preservation. Increasing green trust not just about green logo which customers always sees it on every green product packaging out there, but also the greenness must be communicated through all communication channels. Greenwashing, from many previous research have shown it negative correlation with trust thus lowering greenwashing effect can have positif impact on green trust and further more brand equity can have positif impact too from the green trust. According to Montiel and Ramus (2005), Greenwashing happened because there is no obligation from the companies to publish their green policies, also companies do not need to verify their environmental friendly claims using a third party. Thus by forcing companies to publish their environmental preservation policy might could decreasing the greenwashing effect also pushing the companies to use third party to verify companies claims might also help.

Customer value is the comparison between benefit and cost, from our study we can examine that customer value also have an impact on brand equity thus company must make customer perceived more benefit and lowering the cost that they must sacrifice. It is clear that green products are not able to lower their actual price because the products must pass certain process or validation, but perhaps other cost can be lowered such as the effort from customer when they want to purchase the product, or any other cost that contained when customer purchase the product. Most customers perceived the benefit from the products they bought are the benefit for themselves, perhaps green products can focusing more on the benefit to the customer itself, of course there is the green function as benefit but it will be a good idea if the product also have superior benefit regarding the customer needs in the green products.

Future research can be conducted using more numbers of respondent, thus will give more better and accurate result. Also by adding more variables in hope that the study will give more understanding on how those variables play important role on brand equity.

\section{REFERENCES}

Aaker, D.A. (1991) Managing Brand Equity. New York: Free Press.

Ambler, T. (1995) Brand equity as a relational concept. The Journal of Brand Management, Vol. 2 No.6.

Bagozzi, R. P., \& Yi, Y. (1988). "On the evaluation of structural equation models". Journal of the Academy of Marketing Science, 16(1), 74-94.

Baldauf, A., Cravens, K.S., \& Binder, G. (2003). "Performance consequences of brand equity management: evidence from organization in the value chain". Journal of Product \& Brand Management, 12(4), 220-236.

Berry, L.L. (2000) "Cultivating service brand equity". Journal of the Academy of Marketing Science, 28, (1), 128-137

Chang, Nai-Jen dan Fong, Cher-Min (2010) "Green product quality, green corporate image, green customer satisfaction, and green customer loyalty". African Journal of Business Management, 4,(13), 2836-2844

Chen, Y.-S. (2010) "The drivers of green brand equity: green brand image, green satisfaction, and green trust". Journal of Business Ethics, 93, (2), 307-19.

Chen, Yu-Shan., Chang, Ching-Hsun. (2013) "Towards green trust: The influences of green perceived quality, green perceived risk, and green satisfaction". Management Decision, 51 (1),63 - 82

Crassous, T. and Gassmann (2011) "Gaining competitive advantage through green marketing. How green marketing is used as a competitive advantage?" Marketing report no. Mf:3:2012:037, pp 1-72 
Delmas, M. A., dan Cuerel Burbano, V. (2011). "The drivers of greenwashing".California Management Review, 54 (1), 64.

Durif, F, Boivin, C \& Julien, C (2010), "In Search of a Green Product Definition", Innovative Marketing, vol. 6, no. 1, pp. 23-31.

Farnsworth, C. B. (2000). "Green washing". Builder, 23,(7), 152-158.

Farquhar, Peter H. (1989) "Managing brand equity". Marketing Research 1(3):24-33.

Gan, Christopher ; Wee, Han Yen; Ozanne, Lucie and Kao, TzuHui (2008). Consumers' purchasing behavior towards green products in New Zealand, Innovative Marketing, Volume 4, Issue 1.

Ganesan S. (1994), "Determinats of long-term orientation in buyer-seller relationship", Journal of Marketing, 58, (2),119.

Girrbach (2011). "The Problems with Green Marketing -and How to Solve Them".

http://www.greenbiz.com/blog/2011/09/26/problems-greenmarketing-how-to-solve-them

Hair, J.F., Sarstedt, M., Ringle, C.M. \& Mena, J.A., (2012). "An assessment of the use of partial least squares structural equation modeling in marketing research". Journal of the Academy of Marketing Science, 40(3), 414-433.

Hulland, J. (1999)."Use of partial least squares (PLS) in strategic management research: a review of four recent studies". Strategic Management Journal, 20(2), 195-204

Kamakura, W.A., \& Russel, G.J.(1993). "Measuring brand value with scanner data". International Journal of Research in Marketing, 10(1), 9-22.

Keller, Kevin Lane. (2013) "Strategic Brand Management: Building, Measuring, and Managing Brand Equity" Pearson fourth edition

Kumar, Ravi Shekhar., Dash, Satyabhusan., Purwar, Prem Chandra., (2013) "The nature and antecedents of brand equity and its dimensions". Marketing Intelligence \& Planning, 31 (2), 141 - 159

Laufer, William S. (2003). "Social Accountability and Corporate Greenwashing". Journal of Business Ethics, Volume 43, Issue 3, pp 253-261

Mahesh, (2013). "Consumer's Perceived value, Attitude and Purchase Intention of Green Products". Management Insight, Vol 9, No 1
Makower, Joel (2011) Green Marketing Is Over. Let's Move On. http://www.greenbiz.com/blog/2011/05/16/greenmarketing-over-lets-move?page $=$ full

Montiel, I., \& Ramus C. A. (2005). "When are corporate environmental policies a form of greenwashing?". Business Society, 44(4), 377-414

Moorman, C., Zaltman, G., dan Deshpandé, Rohit, (1992). "Relationships between Providers and Users of Market Research: The Dynamics of Trust within and between Organizations." Journal of Marketing Research (JMR) 29, (3), 314-28.

Netemeyer, R, G. Krishnan, B. Pullig, C. Wang, G. Yagci, M. Deam, D. Ricks, J. Wirth, F. (2004). Developing and validating measures of facets of customer-based brand equity. Journal of business Research, 57(2), 209-224.

Sirdeshmukh, D., Singh, J., Sabol, B., (2002). "Consumer trust, value, and loyalty in relational exchanges". Journal of marketing, 66,(1), 15-37.

Slater, F. S. dan Narver, C, J (2000). "Intelligence Generation and Superior Customer Value". Journal of The Academy Of Marketing Science. Winter

Synovate (2011). "Synovate Survey Reveals Latest Green Habits And Consumption Across The World". http://www.marketresearchworld.net/content/view/3966/77/

Ulaga, W.; Chacour, S. (2001) "Measuring CustomerPerceived Value in Business Markets - A Prerequisite for Marketing Strategy Development and Implementation" Industrial Marketing Management, $30,(6), 525-540$

Veloutsou, Cleopatra, Christodoulides, George and de Chernatony, Leslie. (2013) "A Taxonomy of Measures for Consumer-Based Brand Equity: Drawing on the views of Managers in Europe". Journal of Product \& Brand Management. 22, (24.5.), 238-248

Wang, Y.G., Lo, H.P. (2003) "Customer-focused performance and its key resource-based determinants in dynamic environments". The Journal of Management Development, 22, (6), 483-526.

Yoo, B., Donthu, N. and Lee, S. (2000) "An examination of selected marketing mix elements and brand equity", Journal of the Academy of Marketing Science, 28, (2), 195-211.

Zeithaml Valarie A. (1988) "Consumer Perceptions of Price, Quality and Value: A Means-End Model and Synthesis of Evidence". Journal of Marketing, 52, 2-22. 
